\title{
PROLACTIN-ADRENAL INTERACTIONS IN THE IMMATURE FEMALE RAT
} \author{
with the technical assistance of Uta MEcke \\ Max-Planck-Institute for Biophysical Chemistry, \\ Department of Neurobiology, \\ 34 Göttingen-Nikolausberg (West Germany) \\ * Department of Physiology, East Lansing, \\ Michigan State University, \\ Michigan (U.S.A.)
}

Marie GELATO, J. DibBET*, S. MARShALL*, J. MIEITES* and W. WUTTKE

Both the adrenal glands and prolactin have been shown to participate in the timing of the onset of puberty in female rats. GoRSKI and LAWTON (I972) reported that adrenalectomy up to day 25 significantly delayed vaginal opening and CLEMENs et al. (I969) demonstrated that either injections or median eminence implants of prolactin significantly enhanced vaginal opening. In the adult rat, an adrenal-prolactin interaction has been demonstrated, that is, prolactin has been shown to enhance progesterone (PrVA et al., I973) and corticosterone (L,IS, GiLARDEAU and ChrETIEN, r973) secretion from the adrenals. In light of the aforementioned work, it was thought of interest to study the possible relationship between prolactin and the adrenal glands in the immature female rat. Sprague-Dawley rats were used in all experiments. Prolactin binding studies were performed using methods previously described (GELATo et al., I975). Prolactin binding activity was measured in adrenal microsomal membranes of female rats at $23,28,33,38,43$ and 75 days of age. In a second series of experiments animals were adrenalectomized at 20 days of age and beginning on day $2 \mathrm{I}$ groups of intact and adrenalectomized rats were treated with either prolactin $(0.35 \mathrm{mg} /$ rat twice daily) or progesterone ( $2 \mu \mathrm{g} / \mathrm{rat} /$ day) until the day of vaginal opening or progesterone $(2 \mu \mathrm{g} / \mathrm{rat} /$ day $)$ until 26 days of age. Another group of rats adrenalectomized and adrenalectomized treated with prolactin were decapitated at 25,29 and 33 days of age and at vaginal opening. Sera from these rats were assayed for prolactin using standard radioimmunoassay techniques. A final group of rats were treated with progesterone $(2 \mu \mathrm{g} / \mathrm{rat} /$ day) starting at 8 days of age and continuing until 25 days of age. Vaginal opening was checked in these animals.

Adrenal membrane preparations from immature rats specifically bound a significant amount of radio-labelled prolactin. In adrenal membrane fractions (containing 
Ioo $\mu$ g protein) from 23 and 28 day old rats 85 p. roo of the total radioactivity bound (I0,000 c.p.m.) was able to be displaced by excess unlabelled hormone whereas only $20 \mathrm{p}$. Ioo of the radioactivity bound was able to be displaced from membranes of 75 day old rats.

Adrenalectomy significantly $(P<0.01)$ delayed vaginal opening, $43.6 \pm 0.9$ day as compared to intact and sham control rats, $39.7 \pm 0.5$ days. Prolactin treatment in intact rats advanced puberty by more than one week $(30.5 \pm 0.4$ days) and in adrenalectomized rats returned vaginal opening to that of intact controls ( $40 \pm 0.9$ days $v s .39 .7 \pm 0.5$ days).

The following table shows the serum prolactin levels ( $\mathrm{ng} / \mathrm{ml}$ NIAMDD RP-I) in these rats, decapitated between 17.00 and $18.00 \mathrm{~h}$ on the days indicated.

TABLE I

Serum prolactin levels in intact and adrenalectomized rats, with or without prolactine treatment

\begin{tabular}{|c|c|c|c|c|}
\hline & \multicolumn{3}{|c|}{ Days of Age } & \multirow{2}{*}{ at Vaginal Opening } \\
\hline & 25 & $\underline{-9}$ & 33 & \\
\hline Intact Controls (9) & $9^{\prime} \pm 16$ & $218 \pm 27$ & 350 - 느 67 & $307 \pm 99$ \\
\hline Adrenalectonized (7) $\ldots$ & $31 \pm 3$ & $7 \pm \pm 13$ & $71 \pm 18$ & $145 \pm 28$ \\
\hline $\begin{array}{l}\text { Intact }+ \text { Prolactin }(9) \ldots \ldots \\
\text { Adrenalect. } \quad \text { - Prolactin }\end{array}$ & $52 \pm 12$ & $111 \doteq 5$ & $50 \pm 8$ & $227 \pm 51$ \\
\hline$\pm \operatorname{SEN}(\bar{\tau}) \ldots \ldots \ldots$ & $26 \pm 3$ & $27 \pm 5$ & $4 \geq \pm 6$ & $130 \pm 18$ \\
\hline
\end{tabular}

In all treatment groups serum prolactin levels were significantly depressed $(\mathrm{P}<\mathrm{o} .0 \mathrm{I})$ except at vaginal opening in intact prolactin treated rats. Progesterone treatment in either adrenalectomized rats $(48 \pm 0.9$ days) or in intact ( $42 \pm 0.6$ days) rats significantly delayed vaginal opening when compared to adrenalectomized control ( $44 \pm 0.7$ days) or intact control rats $(37.5 \pm 0.6$ days). These data show that I) immature rat adrenal membrane preparations bind significantly more radio-labelled prolactin than adrenals from adult rats, 2) adrenalectomy and progesterone treatment are both able to delay the onset of puberty, 3) prolactin is able to overcome the effects of adrenalectomy but yet does not enhance vaginal opening as it does in intact rats and 4) the effects of adrenalectomy may be due in part to an alteration of endogenous prolactin levels. Thus the data indicate that prolactin and the adrenals interact in normal sexual development in female rats and that prolactin is possibly a key hormone in the timing of the onset of puberty.

Sexual Maturation, 3rd Workshop August 31, September 3, 1975.

\section{ACKNOWLEDGEMENTS}

Aided in part by the Deutsche Forschungsgemeinschaft Az Wu6o/Z. 


\section{RÉSUMÉ}

\section{INTERACTIONS SURRÉNALES-PROLACTINE CHEZ IA RATTE IMMATURE}

Ies préparations de membranes de surrénales de Ratte immature lient spécifiquement quatre fois plus de prolactine ovine marquée que celles de Ratte adulte. La surrénalectomie retarde significativement l'ouverture vaginale et déprime le niveau de prolactine sérique. On peut, par des injections de prolactine, ramener l'ouverture vaginale à l'âge observé chez les témoins. Un traitement à la progestérone retarde significativement l'ouverture vaginale chez les Rattes entières et provoque un retard supplémentaire chez les Rattes surrénalectomisées. La prolactine semble donc jouer un rôle plus important dans la fonction surrénalienne chez la Ratte immature que chez la Ratte adulte. Les effets de la surrénalectomie doivent être dus en partie à une déficience en prolactine. La prolactine et les surrénales interagissent dans le développement sexuel de la Ratte et la progestérone doit jouer un rôle dans cette interaction.

\section{REFERENCES}

Clemens J. A., Minaguchi H., Story R., Voogt J. L., Meites J., i969. Induction of precocious puberty in female rats by prolactin. Neuroendocrinology, 4, I50-I 56 .

Gelato M., Marshall S., Boudreau M., Bruni J., Campbell G. A., Meites J., ig75. Effects of thyroid and ovaries on prolactin binding activity in rat liver. Endocrinology, 96, 1292-I296.

GoRsKi M., LAwTON I. E., 1972. Timing of prepuberal adrenal-ovarian interaction in the rat. Fifth Annual Meeting, Society for the Study of Reproduction (Abstract).

Lis M., Gilardeau C., Chrétien M., I973. Effect of prolactin on corticosterone production by rat adrenals. Clin. Res., 21, 1027.

Piva F., Gagliano P., Motta M., Martini I.., I973.. Adrenal progesterone : factors controlling its secretion. Endocrinology, 93, II78-II84. 